\title{
UPORABNI MODEL KAO NOVI OBLIK ZAŠTITE IZUMA**
}

Sažetak: Uporabni model je novi oblik zaštite izuma uveden u hrvatsko pravo Zakonom o patentu iz 2020. godine. Njime se stječe isključivo pravo iskorištavati i raspolagati izumom koji je predmet zaštite danom objave registracije uporabnog modela. Vrijedi deset godina od dana podnošenja prijave uporabnog modela, uz plaćanje troškova godišnje naknade za održavanje prava. Postupak se njegove registracije pokreće posebnom prijavom koju Državni zavod za intelektualno vlasništvo formalno ispituje te ne provodi pretraživanje stanja tehnike niti ispituje novost, inventivnu razinu i industrijsku primjenjivost izuma. Određeni se izumi ne mogu zaštititi uporabnim modelom. Zakon o patentu dopušta tzv. grananje prijave patenta i prijave uporabnog modela za isti izum te pretvorbu prijave patenta $u$ prijavu uporabnog modela i obratno. Nositelj uporabnog modela može zahtijevati od Državnog zavoda za intelektualno vlasništvo i potpuno ispitivanje izuma te pretvorbu uporabnog modela u patent. Taj zahtjev može podnijeti najkasnije do isteka sedme godine trajanja uporabnog modela. Treće osobe mogu tražiti poništavanje uporabnog modela tijekom cijelog razdoblja njegove vrijednosti. Nositelju se uporabnog modela na priznaje građanskopravna zaštita u slučaju njegova neovlaštenog korištenja.

Ključne riječi: $\quad$ uporabni model, postupak za registraciju, pretvorba prijave, pretvorba u patent, ništetnost, građanskopravna zaštita

\footnotetext{
Dr. sc. Dionis Jurić, redoviti profesor Pravnog fakulteta Sveučilišta u Rijeci, Hahlić 6, 51000 Rijeka. E-adresa: djuric@pravri.hr. ORCID: https://orcid.org/0000-0001-7725-7531.

** Ovaj je rad izrađen uz potporu projekta Sveučilišta u Rijeci "Pravni aspekti restrukturiranja trgovačkih društava i tranzicija prema novoj kulturi korporativnog upravljanja".
} 


\section{UVOD}

Donošenjem Zakona o patentu (dalje: ZP) iz 2020. godine ${ }^{1} u$ hrvatsko je patentno pravo uveden novi institut zaštite izuma pod nazivom uporabni model. ${ }^{2}$ Ovaj je institut zamijenio dotadašnji konsenzualni patent, koji je uveden Zakonom o patentu iz 1999. godine. ${ }^{3}$ Temeljne su odlike uporabnog modela jednostavniji, brži i jeftiniji postupak priznavanja zaštite izuma, ograničenje oblika izuma koji mogu biti predmetom zaštite, kraće trajanje zaštite u odnosu na patent te ograničenje građanskopravne zaštite uporabnog modela. Načelno se uporabnim modelom štite tzv. mali izumi koji imaju manju inventivnu razinu u odnosu na izume koji se štite patentom. Uporabni je model pogodan za zaštitu izuma koji su nastali radom fizičkih osoba te malih i srednjih poduzetnika, a koji se pojavljuju kao izumitelji. ${ }^{4}$ Njime se štite oni izumi koji imaju kraći vijek ekonomskog iskorištavanja (izumi koji brzo zastarijevaju). ${ }^{5}$

Nedostatak uporabnog modela očituje se u većoj neizvjesnosti opstojnosti zaštite, budući da se ne provodi potpuno ispitivanje patentibilnosti izuma. Naknadno treće osobe mogu zahtijevati poništavanje uporabnog modela, a to dovodi i do nesigurnosti stjecatelja licencije pri njegovu korištenju. ${ }^{6}$ Uporabni model nije univerzalni pravni institut te ga primjenjuju samo neke države. ${ }^{7}$ Pritom postoje razlike u nacionalnom pravnom uređenju tog pravnog instituta. Ne postoji međunarodni pravni okvir za zaštitu uporabnog modela, ali one države koje ga poznaju mogu u okviru međunarodne patentne prijave, podnesene sukladno Ugovoru o suradnji na području patenata (dalje: PCT), predvidjeti i taj oblik zaštite izuma na nacionalnoj razini. ${ }^{8}$ Na razini Europske unije (dalje: EU) Europska je komisija 1997. godine izradila prijedlog Direktive o zaštiti uporabnih modela (dalje: prijedlog Direktive), koji je izmijenila 1999. godine. ${ }^{9}$ Njime se željelo uskladiti nacionalna pravna pravila onih država članica koja uređuju uporabni model te eventualno proširiti njegovu primjenu u države članice koje ga ne uređuju. Budući da

1 Zakon o patentu (NN 16/2020) (HR).

2 Uporabni model je prvi put uređen u njemačkom pravu 1891. godine donošenjem Zakona o uporabnom modelu (njem. Gebrauchsmustergesetz). Ovaj je oblik zaštite izuma predvidjela i Pariška konvencija za zaštitu prava industrijskog vlasništva iz 1883. godine pod nazivom korisni model (franc. model d'utilité). Pri zaštiti uporabnog modela primjenjuju se opća načela Pariške konvencije. Vidi u: Karsten Königer, 'The $125^{\text {th }}$ anniversary of the German utility model - A reason to celebrate?' (2017) 12(2) Journal of Intellectual Property Law and Practice 75; Albert Verona, Pravo industrijskog vlasništva (Informator 1978$) 73$.

3 Na dan 4. siječnja 2021. godine na području Republike Hrvatske vrijedilo je 85 domaćih i 10.955 stranih patenata (ukupno 11.040 patenata) te 266 domaćih i 28 stranih konsenzualnih patenata (ukupno 294 konsenzualna patenta). Vidi: Statistika industrijskog vlasništva (Državni zavod za intelektualno vlasništvo, siječanj 2021) <https://www.dziv.hr/hr/o-zavodu/statistikaind-vlasnistva> pristupljeno 1. siječnja 2021.

4 Pravo na zaštitu izuma uporabnim modelom ima izumitelj ili njegov pravni sljednik. Vidi u: Što je uporabni model? (Državni zavod za intelektualno vlasništvo) 〈http://dziv.hr/hr/intelektualno-vlasnistvo/patenti/sto-je-uporabni-model/> pristupljeno 18. siječnja 2021.; Utility models (World Intellectual Property Organization), <https://www.wipo.int/patents/en/topics/utility_ models.html> pristupljeno 18. siječnja 2021. 1.

5 Alfred Radauer and others, Study on the economic impact of the utility model legislation in selected Member States - Final report (Publications Office of the European Union 2014) 4, 33, 148.

6 Ibid 148.

7 Uporabni model je uređen u nacionalnim pravima 73 države te ga priznaju tri regionalna patentna ureda. U državama članicama Europske unije priznaje se u: Austriji, Bugarskoj, Češkoj, Danskoj, Estoniji, Finskoj, Francuskoj, Grčkoj, Hrvatskoj, Irskoj, Italiji, Mađarskoj, Njemačkoj, Poljskoj, Portugalu, Rumunjskoj, Slovačkoj, Sloveniji i Španjolskoj. Vidi u WIPO (n 5) 4.

$8 \quad$ WIPO (n 5 ) 3.

9 Amended proposal for a European Parliament and Council Directive approximating the legal arrangements for the protection of inventions by utility model (2000/C 248 E/03) COM(1999) 309 final - 97/0356(COD) [2000] OJ C248 E/56. 
države članice nisu mogle postići suglasnost o konačnom tekstu prijedloga Direktive, Europska ga je komisija 2006. godine povukla iz zakonodavnog postupka. ${ }^{10}$

\section{PREDMET ZAŠTITE UPORABNOG MODELA}

Uporabnim modelom može se zaštititi izum koji je nov, ima inventivnu razinu i koji se može industrijski primijeniti (čl. 71. st. 1. ZP-a). Pritom se traži apsolutna novost izuma, što znači da nije sadržan u stanju tehnike na svjetskoj razini. Stanje tehnike čini sve što je učinjeno dostupnim javnosti pisanim ili usmenim putem, uporabom ili na bilo koji drugi način prije dana podnošenja prijave. ${ }^{11}$

Ako je riječ o inventivnoj razini izuma pogodnog za zaštitu uporabnim modelom, traži se da on očigledno ne proizlazi iz stanja tehnike za stručnu osobu iz odgovarajućeg područja. ${ }^{12}$ Time se izjednačava zahtjev inventivnosti izuma pri njegovoj zaštiti uporabnim modelom i patentom. ${ }^{13}$

Uporabnim modelom se ne mogu zaštititi: a) otkrića, znanstvene teorije i matematičke metode, b) estetske tvorevine, c) pravila, upute i metode za izvođenje umnih aktivnosti, igara ili za obavljanje poslova, d) prikazivanje informacija te e) računalni programi (čl. 6. st. 2. $\mathrm{ZP}-\mathrm{a}){ }^{14}$ Riječ je o tvorevinama koje se ne smatraju izumima pa ne mogu ni biti predmetom patentne zaštite.

Posebnost uporabnog modela očituje se i u isključenju zaštite određenih izuma tim oblikom zaštite. Tako se uporabnim modelom ne mogu zaštititi: a) biotehnološki izum, b) izum kemijske ili farmaceutske tvari, c) izum čije je komercijalno iskorištavanje protivno javnom poretku ili moralu te d) izum koji se odnosi na postupak (čl. 71. st. 2. ZP-a). ${ }^{15}$ Ovi se izumi, s

10 Utility models (European Commission) <https://ec.europa.eu/growth/industry/policy/intellectual-property/patents/utilitymodels_en>pristupljeno 18. siječnja 2021.

11 Isto predviđa i § 3. st. 1. austrijskog Zakona o uporabnom modelu (Gebrauchsmustergesetz (BGBl 211/1994) (AT), dalje: GMG). Njemački Zakon o uporabnom modelu (Gebrauchsmustergesetz (BGBl I S 1455/1986 und I S 2541/2017) (DE), dalje: GebrMG) u §1. st. 1. određuje da stanje tehnike čini sve ono što je učinjeno dostupnim javnosti pisanim putem ili upotrebom na području SR Njemačke prije dana podnošenja prijave (relativna novost). Usmene objave i upotreba izuma izvan područja SR Njemačke ne isključuje njegovu novost. Pritom u njemačkom i austrijskom pravu izum ne gubi novost ako je opisan ili uporabljen u razdoblju od šest mjeseci prije dana podnošenja prijave od strane podnositelja prijave ili njegovog pravnog prednika ili je do toga došlo očitom zloupotrebom u odnosu na podnositelja prijave ili njegovog pravnog prednika. Prijedlog Direktive u čl. 5. predviđa apsolutnu novost izuma. Vidi u: Radauer (n 6) 32, 51, 143.

12 Isto i $§ 1$. GebrMG-a i $§ 1$ GMG-a.

13 U Njemačkoj je do 2006. godine, a u Austriji do 2011. godine bio predviđen niži stupanj inventivnosti izuma kao uvjeta za njegovu zaštitu uporabnim modelom, u odnosu na patent. Presudama vrhovnih sudova su te razlike ukinute, te je kriterij inventivnosti izuma izjednačen i za patent i za uporabni model. Vidi u: Radauer (n 6) 31, 51, 147. U čl. 6. prijedloga Direktive je inventivna razina izuma određena tako da on predstavlja unapređenje te nije vrlo očit za stručnu osobu iz odgovarajućeg područja, uzimajući u obzir stanje tehnike. Unapređenje mora biti praktične ili tehničke naravi. Time je prijedlog Direktive prihvatio niži stupanj inventivnosti izuma pogodnog za zaštitu uporabnim modelom.

14 Isto predviđa i § 1. st. 2. njemačkog GebrMG-a, s time da umjesto računalnih programa navodi biotehnološke izume. Austrijski GMG u §1. st. 3. također predviđa izuzetke kao i ZP, s time da se uporabnim modelom može zaštititi programski algoritam na kojem se zasniva računalni program te postupci. Vidi u: Radauer (n 6) 51. Prijedlog Direktive u čl. 3. ima isti sadržaj kao i ZP, izuzimajući računalne programe.

15 U § 2. GebrMG-a određeno je da se uporabnim modelom ne mogu zaštititi: a) izum čije je komercijalno iskorištavanje protivno javnom poretku ili moralu, b) biljne sorte i životinjske pasmine te c) izum koji se odnosi na postupak. U § 2. GMG-a određuje se 
druge strane, mogu štititi patentom, osim onih čije je komercijalno iskorištavanje protivno javnom poretku ili moralu. ${ }^{16}$

\section{POSTUPAK ZA REGISTRACIJU UPORABNOG MODELA I PRAVO PRVENSTVA}

Postupak za registraciju uporabnog modela pokreće se podnošenjem prijave uporabnog modela Državnom zavodu za intelektualno vlasništvo (dalje: DZIV), pri čemu ona može sadržavati najviše deset patentnih zahtjeva (čl. 73. ZP-a). ${ }^{17}$ Prijava mora sadržavati: a) zahtjev za priznavanje uporabnog modela, b) opis izuma, c) crteže, d) patentne zahtjeve te e) sažetak. ${ }^{18}$ Jedna se prijava podnosi za samo jedan izum, ili više njih, ako su oni međusobno tako povezani da se njima ostvaruje jedinstvena izumiteljska zamisao (jedinstvo izuma). ${ }^{19}$

DZIV utvrđuje datum podnošenja prijave uporabnog modela i provodi njezino formalno ispitivanje. ${ }^{20}$ Ne provodi se pretraživanje stanja tehnike ${ }^{21}$ niti se ispituje novost, inventivna razina

da se uporabnim modelom ne mogu zaštititi: a) izum čija je objava ili iskorištavanje protivno javnom poretku ili moralu, b) izum koji se odnosi na dijagnostičke ili kirurške postupke ili postupke liječenja ljudi, osim proizvoda, posebno tvari i smjesa koje se primjenjuju u tim postupcima te c) biljne sorte, životinjske pasmine i biološki materijal, kao i postupci za njihovu proizvodnju. Prijedlog Direktive u čl. 4. ima isti sadržaj kao i ZP.

16 To isključenje zaštite određenih izuma konsenzualnim patentom nije postojalo prema prijašnjem ZP-u iz 2003. godine (NN 173/2003, 87/2005, 76/2007, 30/2009, 128/2010, 49/2011, 76/2013, 46/2018) (HR).

17 U njemačkom i austrijskom pravu nema ograničenja broja patentnih zahtjeva.

18 Na sadržaj prijave uporabnog modela primjenjuju se odredbe ZP-a o sadržaju prijave patenta.

19 Prema prijašnjem ZP-u iz 2003. godine postupak se pokretao podnošenjem prijave patenta koju je formalno ispitivao DZIV. Ako je ona bila uredna i ako je bio utvrđen datum njezina podnošenja, upisivala se u Registar prijava patenata. Potom se prijava objavljivala u glasilu DZIV-a nakon isteka osamnaest mjeseci od datuma njezina podnošenja, odnosno od datuma priznatoga prvenstva. Time je ona ulazila u stanje tehnike. Prijava se mogla objaviti na zahtjev podnositelja i prije isteka tog roka, ali ne prije isteka roka od tri mjeseca od datuma podnošenja DZIV-u. Potom je podnositelj mogao u roku od šest mjeseci od datuma objave prijave podnijeti: a) zahtjev za priznanje patenta provedbom postupka potpunog ispitivanja prijave patenta, ili b) zahtjev za priznanje patenta bez potpunog ispitivanja prijave patenta (konsenzualni patent). Zahtjev za priznanje konsenzualnog patenta se objavljivao u glasilu DZIV-a u roku od tri mjeseca od datuma podnošenja. Svaka je fizička ili pravna osoba mogla u roku od šest mjeseci nakon objave zahtjeva DZIV-u podnijeti prigovor protiv priznanja konsenzualnoga patenta, ili zahtjev za provođenje postupka potpunog ispitivanja.

20 DZIV ispituje je li uplaćena upravna pristojba i naknada troškova postupka za formalno ispitivanje prijave, ispitivanja pretpostavki za registraciju te troškova za prve dvije godine održavanja uporabnog modela, je li u njoj naznačen izumitelj, ima li propisani sadržaj i jesu li uz nju dostavljeni propisani prilozi. Ispituje i je li predmet zaštite izum koji nije isključen iz zaštite uporabnim modelom (čl. 74. st. 1. ZP-a). Iznos je upravne pristojbe i naknade troškova pri podnošenju prijave uporabnog modela određen Pristojbenom tarifom iz Zakona o upravnim pristojbama u području prava intelektualnog vlasništva (NN 64/2000, 160/2004, 62/2008, 30/2009, 49/2011) (HR) te čl. 9.a Uredbe o naknadama za posebne troškove i troškove za pružanje informacijskih usluga DZIV-a (dalje: Uredba o naknadama) (NN 109/2011, 96/2013, 89/2020) (HR). Podnositelj prijave koji je izumitelj plaća polovicu iznosa propisanih troškova (troškovi postupka formalnog ispitivanja prijave, ispitivanja zahtjeva za pretvorbu prijave, potpunog ispitivanja uporabnog modela, objave registracije uporabnog modela i izdavanja spisa o uporabnom modelu te godišnje naknade za održavanja uporabnog modela) (čl. 14. Uredbe o naknadama).

21 U njemačkom pravu patentni ured može na zahtjev podnositelja prijave provesti pretraživanje stanja tehnike i izraditi izvješće o tome (§ 7. st. 1. GebrMG-a). U austrijskom je pravu obvezatno pretraživanje stanja tehnike i izrada izvješća (§ 19. GMG-a). Rezultati izvješća o pretraživanju stanja tehnike ne obvezuju. Prijedlog Direktive u čl. 16. propisuje izradu izvješća o pretraživanju stanja tehnike na zahtjev podnositelja prijave ili treće zainteresirane osobe, koji moraju podmiriti troškove pretraživanja. To je izvješće obvezatno ako naknadno dođe do pravnih postupaka radi ostvarivanja prava koja proizlaze iz uporabnog modela (poništavanje ili građanskopravna zaštita). Pretraživanjem stanja tehnike omogućava se ocjena novosti i inventivnosti izuma koji se želi zaštititi uporabnim modelom, što doprinosi podnošenju prijava uporabnog modela za izume koji su patentabilni te opstojnosti zaštite uporabnog modela u slučaju naknadnih zahtjeva trećih osoba za njegovim poništavanjem. Vidi u: Radauer (n 6) 149. 
te industrijska primjenjivost izuma (čl. 74. st. 2. i 3. ZP-a). ${ }^{22}$ Potpuno će se ispitivanje uporabnog modela provoditi ako nositelj uporabnog modela naknadno to zatraži sukladno čl. 77. ZP-a ili ako ovlaštene osobe podnesu prijedlog za poništavanje uporabnog modela sukladno čl. 112. 113. ZP-a. Ako prijava ima nedostataka, DZIV o tome obavještava podnositelja prijave te ga poziva ispraviti nedostatke u roku koji ne može biti kraći od dva mjeseca niti dulji od tri mjeseca od dana primitka obavijesti (čl. 74. st. 3. ZP-a). Podnositelj prijave može nakon toga izmijeniti opis, patentne zahtjeve i crteže, uz uvjet da izmjenu podnese DZIV-u istodobno s odgovorom na rezultat ispitivanja (čl. 74. st. 5. ZP-a). Prijava se uporabnog modela ne objavljuje (čl. 74. st. 7. ZP-a).

Ako DZIV utvrdi da prijava ne ispunjava sve uvjete za registraciju uporabnog modela iz čl. 74. ZP-a, donosi rješenje o odbijanju uporabnog modela (čl. 75. ZP-a). Ako ona ispunjava sve te uvjete, o tome obavještava podnositelja prijave te ga poziva da se suglasi s prijedlogom konačnog sadržaja prijave za koju se namjerava priznati uporabni model ili da zatraži pretvorbu prijave uporabnog modela u prijavu patenta u roku od jednog mjeseca od dana primitka poziva. U tom roku podnositelj prijave mora platiti i naknadu troškova za tiskanje objave podataka o registraciji uporabnog modela i izdavanje isprave o uporabnom modelu te spisa uporabnog modela (čl. 76. st. 1. i 2. ZP-a). ${ }^{23}$ Ako on to učini, smatrat će se da je suglasan s predloženim tekstom te DZIV donosi rješenje o registraciji uporabnog modela prema predloženom konačnom sadržaju prijave (čl. 76. st. 3. ZP-a). ${ }^{24}$ Podaci o registraciji uporabnog modela upisuju se u registar uporabnih modela te se to objavljuje u glasilu DZIV-a (čl. 76. st. 8. ZP-a). Time izum zaštićen uporabnim modelom ulazi u stanje tehnike.

Uredna prijava uporabnog modela stječe pravo prvenstva u odnosu na sve kasnije prijave za isti izum od dana njezina podnošenja. Osoba koja je podnijela urednu prijavu patenta ${ }^{25}$ ima pravo prvenstva od dana te prijave radi podnošenja prijave uporabnog modela ili pretvorbe iz prijave patenta u prijavu uporabnog modela. Prijavu uporabnog modela za isti izum mora podnijeti u roku od dvanaest mjeseci od dana podnošenja prijave patenta te uz uvjet da prvenstvo već nije zahtijevano za prijavu patenta na čije se prvenstvo namjerava pozvati (čl. 72. st. 1. ZP-a). Podnositelj prijave uporabnog modela mora zahtjev za priznavanje prvenstva podnijeti najkasnije u roku od dva mjeseca od dana podnošenja te prijave (čl. 72. st. 2. ZP-a). Pritom se odredbe čl. 43. i 44. ZP-a o međunarodnom pravu prvenstva primjenjuju na odgovarajući način i na nacionalno prvenstvo uporabnog modela (čl. 72. st. 3. ZP-a). ${ }^{26}$ Time se omogućava podnositelju prijave patenta zaštititi izum u razdoblju od podnošenja prijave do donošenja rješenja o priznanju patenta (pendentni patenti) ${ }^{27}$ uporabnim modelom, odnosno, ovisno o rezultatima pretraživanja stanja tehnike, pretvoriti prijavu patenta u prijavu uporabnog modela. ${ }^{28}$

22 Prije podnošenja prijave uporabnog modela podnositelj bi trebao samostalno pretražiti stanje tehnike i utvrditi patentibilnost izuma kako bi unaprijed mogao ocijeniti opstojnost zaštite uporabnog modela u budućnosti.

23 Ti su troškovi određeni u čl. 11., 12. i 46. Uredbe o naknadama.

24 Ako podnositelj prijave ima primjedbi na predloženi konačni tekst sadržaja prijave, o tome mora obavijestiti DZIV, navesti razloge za to i dostaviti izmijenjeni tekst patentnih zahtjeva. Te primjedbe DZIV može uzeti u obzir i donijeti rješenje o registraciji uporabnog modela sukladno izmijenjenim patentnim zahtjevima ili ih odbiti i donijeti rješenje o registraciji prema prijedlogu konačnog teksta sadržaja prijave (čl. 76. st. 4.-6. ZP-a).

25 Može se raditi o nacionalnoj prijavi patenta ili prijavi patenta koja ima učinak u RH (npr. međunarodna ili europska prijava patenta).

26 To predviđa i čl. 17. te 18. prijedloga Direktive.

27 Građanskopravna se zaštita pruža samo nositeljima priznatih patenata te podnositeljima prijava patenata nakon njihove objave.

28 To tzv. grananje prijave patenta i prijave uporabnog modela za isti izum poznaje i njemačko (§ 5. i 6. GebrMG-a) i austrijsko pravo (§ 15.a, 16.a i 16.b GMG-a). To je osobito pogodno za zaštitu izuma s kraćim vijekom ekonomskog iskorištavanja (npr. potrošačka elektronika). Ako isti izum kasnije bude zaštićen patentom, prestaje uporabni model. Vidi u: Radauer (n 6) 32-34, 51. 


\section{PRETVORBA PRIJAVE}

Na zahtjev podnositelja prijave DZIV može donijeti rješenje o pretvorbi prijave uporabnog modela u prijavu patenta ili pretvorbi prijave patenta u prijavu uporabnog modela (čl. 78. st. 1. ZP-a). ${ }^{29}$ Zahtjev za pretvorbu prijave uporabnog modela u prijavu patenta podnositelj može podnijeti do donošenja rješenja o odbijanju ili registraciji uporabnog modela te uz plaćanje upravne pristojbe i naknade troškova postupka (čl. 78. st. 2. ZP-a). Ako podnositelj zahtijeva pretvorbu prijave patenta u prijavu uporabnog modela, to može učiniti najkasnije u roku od šest mjeseci od dana objave izvješća o pretraživanju stanja tehnike u glasilu DZIV-a (čl. 78. st. 3. ZP-a). Pretvorena prijava zadržava dan podnošenja prijave uporabnog modela, odnosno prijave patenta radi ostvarivanja prava prvenstva (čl. 78. st. 4. i čl. 72. ZP-a). ${ }^{30}$

\section{PRAVNI UČINCI REGISTRIRANOG UPORABNOG MODELA}

Pravni učinci registriranog modela istovjetni su učincima priznatog patenta. Uporabni model traje deset godina računajući od dana podnošenja prijave uporabnog modela (čl. 87. st. 2. $\mathrm{ZP}-\mathrm{a}){ }^{31} \mathrm{Za}$ održavanje prava iz uporabnog modela plaća se godišnja naknada troškova za treću i svaku sljedeću godinu računajući od dana podnošenja prijave. ${ }^{32}$ Ako naknada ne bude plaćena u tim rokovima, može se platiti u dodatnom roku od šest mjeseci, uz plaćanje dodatne naknade troškova. ${ }^{33}$ DZIV obavještava nositelja uporabnog modela o propuštanju plaćanja naknade, posljedicama neplaćanja te mogućnosti njezina plaćanja u dodatnom roku (čl. 88. ZP-a). Ako se naknada troškova za održavanje prava ne plati, uporabni model prestaje sljedećeg dana od dana isteka roka za plaćanje iz čl. 88. st. 3. te se to objavljuje u glasilu DZIV-a (čl. 90. ZP-a). ${ }^{34}$

Nositelj uporabnog modela stječe isključivo pravo iskorištavati i raspolagati izumom koji je predmet zaštite danom objave registracije uporabnog modela (čl. 93. i 96. ZP-a). Trećim

29 Troškovi postupka ispitivanja zahtjeva za pretvorbu prijave određeni su u čl. 9.b Uredbe o naknadama.

30 Pretvorbu prijave uređuje i austrijsko pravo u § 21. GMG-a te ju predviđa čl. 18. prijedloga Direktive. U njemačkom pravu to nije dopušteno.

31 Isti rok trajanja uporabnog modela određuje i § 23. st. 1. GebrMG-a i § 6. GMG-a. U njemačkom pravu taj rok počinje teći od dana podnošenja prijave, a ističe posljednjeg dana mjeseca u kojem je prijava podnesena. U austrijskom pravu taj rok počinje teći od dana objave registriranog uporabnog modela, a ističe posljednjeg dana mjeseca u kojem je prijava podnesena. Prijedlog Direktive u čl. 19. propisuje da uporabni model traje šest godina od dana podnošenja prijave, uz mogućnost produljenja zaštite dvaput po dvije godine, ali ukupno ne dulje od deset godina od dana podnošenja prijave. Pri prvom produljenju zaštite mora se zatražiti i izrada izvješća o pretraživanju stanja tehnike, a zahtjevi za produljenje podnose se šest mjeseci prije isteka prethodnog razdoblja trajanja zaštite.

32 Ti su troškovi određeni u čl. 13. Uredbe o naknadama. Troškovi održavanja vrijednosti prava jednaki su za patent i uporabni model te rastu sa svakom godinom produljenja.

33 Tada se propisana godišnja naknada udvostručuje.

34 Plaćanje godišnje naknade za održavanje prava iz uporabnog modela, kao i pravnu posljedicu njezina neplaćanja, predviđa $\S 23$. GebrMG-a. Ta se naknada plaća po isteku tri, šest i osam godina trajanja zaštite uporabnog modela. Slično je uređeno $i$ u austrijskom pravu, s time da se godišnja naknada za održavanje prava iz uporabnog modela plaća za drugu i svaku sljedeću godinu trajanja zaštite. Patentni ured može nositelju uporabnog modela umjesto plaćanja godišnje naknade ponuditi i plaćanje paušalne naknade po isteku tri i šest godina trajanja zaštite. 
je osobama zabranjeno iskorištavati uporabni model bez odobrenja nositelja. ${ }^{35}$ Isključiva se prava nositelja uporabnog modela ne primjenjuju ako izum treće osobe iskorištavaju u osobne i nekomercijalne svrhe, radi obavljanja pokusa te ako postoji pravo korištenja izuma ranijeg korisnika (čl. 98. i 100. ZP-a). ${ }^{36}$ Uporabni se model može prenijeti na treće osobe i ustupiti na korištenje trećoj osobi ugovorom o licenciji (čl. 107. i 108. ZP-a). On se može naslijediti, založiti, ovršiti te biti dio stečajne mase (čl. 110. i 111. ZP-a). ${ }^{37}$

\section{POTPUNO ISPITIVANJE UPORABNOG MODELA}

Nositelj uporabnog modela može zahtijevati od DZIV-a provedbu postupka potpunog ispitivanja izuma koji je zaštićen uporabnim modelom, uz plaćanje upravne pristojbe i naknade troškova postupka izrade izvješća o pretraživanju stanja tehnike i postupka potpunog ispitivanja (čl. 77. st. 1. ZP-a). ${ }^{38}$ Taj zahtjev može podnijeti najkasnije do isteka sedme godine trajanja uporabnog modela te ga ne može povući (čl. 77. st. 2. ZP-a). ${ }^{39}$ Postupak potpunog ispitivanja uporabnog modela provodi se sukladno odredbama ZP-a o postupku potpunog ispitivanja uvjeta za priznanje patenta (čl. 77. st. 4. ZP-a). ${ }^{40}$ Ako DZIV utvrdi da izum koji je zaštićen uporabnim modelom ispunjava uvjete iz čl. 62. st. 1. t. 1.-3. ZP-a za priznanje patenta, njegovom se nositelju izdaje rješenje o priznanju patenta (čl. 77. st. 3. ZP-a). Ako ti uvjeti nisu ispunjeni, DZIV proglašava uporabni model ništetnim po službenoj dužnosti (čl. 77. st. 5. ZP-a). U registar uporabnih modela DZIV upisuje podatak o pretvorbi uporabnog modela u patent ili o njegovu proglašavanju ništetnim te to objavljuje u svojem glasilu (čl. 77. st. 2. ZP-a). Time se

35 Bez odobrenja nositelja uporabnog modela svakoj trećoj osobi zabranjeno je izrađivati, nuditi, stavljati u promet ili upotrebljavati proizvod koji je predmet uporabnog modela te uvoziti i skladištiti proizvod u te svrhe (čl. 93. st. 1. t. 1. ZP-a). Također je zabranjeno svakoj trećoj osobi nuditi isporuku i isporučivati proizvod koji čini bitni element izuma osobama koje nisu ovlaštene za iskorištavanje toga izuma ako je ponuđaču ili isporučitelju poznato ili mu je iz okolnosti slučaja moralo biti poznato da je taj proizvod namijenjen za izvođenje tuđeg izuma. To se neće primjenjivati ako je taj proizvod uobičajen na tržištu, osim ako ponuđač ili isporučitelj ne potiče treće osobe na poduzimanje zabranjenih radnji (čl. 93. st. 3. i 4. ZP-a).

36 Isti se pravni učinci uporabnog modela priznaju i u njemačkom (§ 11.-13. GebrMG-a) te austrijskom pravu (§ 4.-5. GMG-a). To predviđa i čl. 20. prijedloga Direktive. Uporabni model može biti i predmetom prisilne licencije u njemačkom pravu (§ 20. GebrMG-a).

37 Prijenos prava, licencija, zalog, ovrha i stečaj uporabnog modela upisuju se u registar uporabnih modela (čl. 22. t. 25. ZP-a).

38 Ti su troškovi određeni u čl. 9.c i 10. Uredbe o naknadama.

39 Prijašnji ZP iz 2003. godine je u čl. 46. predviđao da se zahtjev za potpunim ispitivanjem konsenzualnog modela i njegovu pretvorbu u patent mogao podnijeti tijekom cijelog desetogodišnjeg trajanja konsenzualnog patenta te ga je mogla podnijeti svaka fizička ili pravna osoba. Svaka je fizička ili pravna osoba mogla u roku od šest mjeseci nakon objave zahtjeva za priznanje konsenzualnog patenta DZIV-u podnijeti zahtjev za provođenje postupka njegova potpunog ispitivanja. Nositelj konsenzualnog patenta je morao podnijeti zahtjev za potpunim ispitivanjem i ako je bio podnesen prijedlog za proglašenje konsenzualnog patenta ništetnim (čl. 81. st. 9.) te ako je podnosio tužbu za naknadu štete koja mu je nastala neovlaštenom uporabom konsenzualnog patenta od trećih osoba (čl. 95.f st. 2.). To je bila pretpostavka za ostvarivanje pravne zaštite priznatog konsenzualnog patenta. Vidi u: Prijedlog Zakona o izmjenama i dopunama Zakona o patentu, s konačnim prijedlogom Zakona (Vlada Republike Hrvatske, Zagreb, Svibanj 2007) 〈https://www.iusinfo.hr/AppendixExtCro/RDOCSB_HR/ent_id_1684.PDF> pristupljeno 22. siječnja 2021. 3-4. Sada taj zahtjev može podnijeti samo nositelj uporabnog modela te se ograničava razdoblje u kojem to može učiniti radi ostvarivanja pravne sigurnosti i očuvanja kontinuiteta zaštite izuma. Pritom je svrha zahtjeva pretvaranje uporabnog modela u patent. Vidi u: Nacrt prijedloga Zakona o patentu (Vlada Republike Hrvatske, Zagreb, Travanj 2019) <https://esavjetovanja.gov.hr/Econ/MainScreen? EntityId=10742> pristupljeno 22. siječnja 2021. 3-4.

40 Protiv zahtjeva nositelja uporabnog modela nisu dopuštene primjedbe trećih osoba na patentibilnost izuma te se on ne objavljuje. Ako DZIV donese rješenje o priznanju patenta, to se upisuje u registar patenata, nositelju patenta se izdaje patentna isprava te mu se izdaje patentni spis. Priznanje patenta objavljuje se u glasilu DZIV-a. U registar se uporabnih modela upisuje podatak o zahtjevu za potpuno ispitivanje uvjeta za priznanje patenta (čl. 22. t. 19. ZP-a). 
nositelju uporabnog modela dopušta njegova pretvorba u patent, ali snosi rizik podnošenja tog zahtjeva, budući da ga ne može povući te, ovisno o rezultatima ispitivanja, može doći do poništavanja uporabnog modela. ${ }^{41}$

\section{PONIŠTAVANJE UPORABNOG MODELA}

Tijekom postupka za registraciju uporabnog modela treće osobe ne mogu stavljati prigovore na njegovu prijavu te se ona ne objavljuje. Ne obavlja se pretraživanje stanja tehnike niti se izum potpuno ispituje. Treće osobe mogu naknadno tražiti poništavanje uporabnog modela za cijelo vrijeme njegova trajanja ako nisu bili ispunjeni uvjeti za zaštitu. Postupak provodi DZIV. $^{42}$

Prijedlog za proglašenje uporabnog modela ništetnim, djelomično ili u cijelosti, u svako doba može podnijeti bilo koja pravna ili fizička osoba, državni odvjetnik ili DZIV po službenoj dužnosti (čl. 113. st. 4. ZP-a). ${ }^{43}$ Razlozi za poništavanje uporabnog modela jesu: a) ako se izum, sukladno čl. 71. ZP-a, ne može zaštititi uporabnim modelom, b) ako izum nije bio nov, nije imao inventivnu razinu ili nije bio industrijski primjenjiv na dan podnošenja prijave uporabnog modela, c) ako izum nije bio opisan na dovoljno jasan i detaljan način da ga stručna osoba iz odgovarajućeg područja može izvesti, d) ako predmet zaštite izlazi izvan sadržaja prijave uporabnog modela kako je podnesena te e) ako je priznat na ime osobe koji nije imala pravo na zaštitu izuma uporabnim modelom (čl. 112. ZP-a). ${ }^{44}$

Ako je prijedlog uredan, DZIV ga dostavlja nositelju uporabnog modela ta ga poziva da u roku od jednog mjeseca, ali ne dulje od dva mjeseca od dana primitka zaključka, dostavi svoj odgovor i izmijeni, kada je primjenjivo, opis, patentne zahtjeve i crteže (čl. 115. st. 1. ZP-a). ${ }^{45}$ DZIV ispituje razloge zbog kojih se predlaže poništavanje uporabnog modela, a koji su navedeni u prijedlogu. On može po službenoj dužnosti ispitati i druge razloge koji nisu navedeni u prijavi, ako bi oni doveli u pitanje održavanje uporabnog modela u vrijednosti (čl. 115. st. 3. ZP-a). Ako DZIV utvrdi da prijedlog nije osnovan, donosi rješenje o odbijanju prijedloga za proglašenje uporabnog modela ništetnim (čl. 115. st. 4. ZP-a). Ako utvrdi da postoji jedan od

41 To nije predviđeno u njemačkom i austrijskom pravu.

42 Postupak proglašenja uporabnog modela ništetnim uređuju i §15.-17. GebrMG, §28.-29. GMG-a te čl. 25. prijedloga Direktive.

43 DZIV može po službenoj dužnosti nastaviti postupak ako podnositelj prijedloga za proglašenje ništetnosti u tijeku postupka odustane od prijedloga (čl. 117. st. 1. ZP-a). Podnositelj prijedloga mora platiti upravnu pristojbu i naknadu troškova postupka za poništavanje uporabnog modela te dostaviti dokaze. Ako je prijedlog nepotpun, DZIV će zaključkom pozvati podnositelja da ga u roku od dva mjeseca od dana primitka zaključka upotpuni (čl. 114. ZP-a). Troškovi postupka za poništavanje uporabnog modela određeni su u čl. 17. Uredbe o naknadama. njemačkom pravu traži relativna novost izuma pa će biti teže ostvariti poništavanje uporabnog modela.

45 DZIV poziva zaključkom stranke u postupku za poništavanje uporabnog modela (podnositelja prijedloga i nositelja uporabnog modela) onoliko puta koliko je potrebno da u roku od dva mjeseca od dana primitka zaključka dostave svoje primjedbe na podneske druge stranke, a svi pozivi i odgovori na njih dostavljaju se svim strankama u postupku (čl. 115. st. 2. ZP-a). On može održati i usmenu raspravu, ako ocijeni da je to nužno za utvrđivanje činjenica bitnih za donošenje odluke (čl. 115. st. 10. ZP-a). 
razloga za poništavanje uporabnog modela, donosi rješenje o proglašenju uporabnog modela ništetnim (čl. 115. st. 5. ZP-a). ${ }^{46}$

Uporabni model od početka neće imati učinke navedene u čl. 93. ZP-a u mjeri u kojoj je proglašen ništetnim (čl. 118. ZP-a). Podatak o njegovu poništavanju DZIV upisuje u registar uporabnih modela te to objavljuje u svojem glasilu po pravomoćnosti rješenja o proglašenju uporabnog modela ništetnim (čl. 119. st. 1. ZP-a). ${ }^{47}$ Ako je uporabni model održan u vrijednosti u izmijenjenom obliku, DZIV objavljuje novi spis uporabnog modela istodobno s donošenjem rješenja o njegovu djelomičnom poništavanju (čl. 119. st. 2. ZP-a).

\section{GRAĐANSKOPRAVNA ZAŠTITA UPORABNOG MODELA}

Pri građanskopravnoj zaštiti uporabnog modela u usporednom pravu u načelu primjenjuju se isti standardi kao i pri zaštiti patenta od povreda isključivih prava nositelja koje počine treće osobe. ${ }^{48}$ To pridonosi atraktivnosti korištenja uporabnog modela pri zaštiti izuma, ali valja voditi računa i o tome da je riječ o izumima koji nisu potpuno ispitani. Stoga se za ostvarivanje građanskopravne zaštite često zahtijeva i ispunjavanje dodatnih uvjeta (npr. pretraživanje stanja tehnike i izrada izvješća o tome).

ZP u čl. 138. st. 1. i 2. određuje da zaštitu isključivih prava koja proizlaze iz patenta mogu ostvariti nositelj patenta i stjecatelj licencije u mjeri u kojoj je na to ovlašten na temelju pravnog posla ili zakona (priznati patenti) te podnositelj prijave patenta i stjecatelj isključive licencije nakon objave prijave patenta (patenti za koje još nije objavljeno priznanje) ${ }^{49} \mathrm{~S}$ druge strane, zaštitu isključivih prava ne može zahtijevati nositelj uporabnog modela (čl. 138. st. 3. ZP-a). Time se izumitelji demotiviraju pri korištenju uporabnog modela kao oblika zaštite izuma, budući da ne-

46 Ako DZIV utvrdi da uporabni model treba održati u vrijednosti, ali u izmjenjenom obliku (djelomična ništetnost), o tome obaviještava stranke u postupku te iz poziva da u roku od dva mjeseca od dana primitka zaključka podnesu obrazložene primjedbe na sadržaj patentih zahtjeva na temelju kojih namjerava održati uporabni model u vrijednosti, ako s njim nisu suglasne. Ako se one ne suglase s tim tekstom, DZIV može nastaviti s postupkom za poništavanje uporabnog modela (čl. 115. st. 6. ZP-a). Ako su stranke suglasne $s$ tekstom ili se nisu očitovale na njega u ostavljenom roku, DZIV donosi rješenje o djelomičnom proglašenju uporabnog modela ništetnim, kojim ga održava u vrijednosti u izmijenjenom obliku, uz uvjet da njegov nositelj plati troškove za tiskanje novog spisa uporabnog modela u roku od dva mjeseca (čl. 115. st. 7. ZP-a). Ako to nositelj ne učini, DZIV rješenjem proglašava uporabni model ništetnim u granicama prijedloga za njegovo poništenje (čl. 115. st. 8. ZP-a).

47 U registar se upisuje dan podnošenja, podnositelj te vrsta i dan odluke DZIV-a u povodu prijedloga za proglašenje uporabnog modela ništetnim (čl. 22. t. 23. ZP-a).

48 Razlika postoji u trajanju zaštite uporabnog modela u odnosu na patent, a u nekim je pravima pretpostavka za podnošenje tužbi protiv trećih osoba koje su povrijedile uporabni model provedba pretraživanja stanja tehnike i izrada izvješća o tome (npr. Kina). Vidi u Radauer (n 6) 152.-54.

Oni mogu podnositi tužbe protiv trećih osoba radi utvrđivanja prava na zaštitu, povrede prava navođenja izumitelja, neovlaštenog poduzimanja radnji kojima se vrijeđaju isključiva prava nositelja patenta, oduzimanja i uništenja robe kojom je počinjena povreda, naknade štete, uobičajene naknade i koristi stečene bez osnove, naknade štete zbog povrede prava iz prijave patenta te objave presude. Oni mogu zahtijevati i dostavu podataka te određivanje privremenih mjera zbog povrede patenta ili za osiguranje dokaza. Predviđene su i novčane kazne za prekršitelje. Tužba za naknadu štete može se podnijeti u roku od tri godine otkad je oštećenik doznao za štetu i štetnika, ali ne poslije isteka roka od pet godina od dana nastanka štete (čl 230. st. 1.-2. Zakona o obveznim odnosima (NN 35/2005, 41/2008, 125/2011, 78/2015, 29/2018) (HR). Parnične postupke radi povreda prava industrijskog vlasništva provode u prvom stupnju trgovački sudovi, a u drugom stupnju Visoki trgovački sud (čl 34.b t. 8. i čl. 34.c t. 2. Zakona o parničnom postupku (SL SFRJ 4/1977, 36/1977, 36/1980, 6/1980, 69/1982, 43/1982, 58/1984, 74/1987, 57/1989, 20/1990, 27/1990, 35/1991 - NN 53/1991, 91/1992, 112/1999, 129/2000, 88/2001, 117/2003, 88/2005, 2/2007, 96/2008, 84/2008, 123/2008, 57/2011, 148/2011, 25/2013, 89/2014, 70/2019) (HR). 
maju učinkovitih pravnih instrumenata pri povredama njihovih registriranih uporabnih modela. ${ }^{50} \mathrm{Tu}$ će pravnu zaštitu moći ostvariti samo ako zatraže pretvorbu uporabnog modela u patent sukladno čl. 77. ZP-a. Pritom valja voditi računa da zahtjev za potpunim ispitivanjem uporabnog modela mogu podnijeti do isteka sedme godine trajanja uporabnog modela.

\section{PRESTANAK UPORABNOG MODELA}

Do prestanka uporabnog modela može doći: a) protekom desetogodišnjeg razdoblja trajanja uporabnog modela, b) ako nositelj ne plati godišnju naknadu za održavanje prava iz uporabnog modela (čl. 90. ZP-a), c) ako se nositelj odrekne prava iz uporabnog modela u cijelosti (čl. 91. ZP-a), ${ }^{51}$ d) smrću fizičke osobe, odnosno prestankom pravne osobe koja je nositelj uporabnog modela, ako on nije prešao na njegove nasljednike ili pravne sljednike (čl. 92. ZP-a), e) poništenjem uporabnog modela u cijelosti u povodu prijedloga za proglašenje uporabnog modela ništetnim (čl. 118. i 119. ZP-a) te f) poništenjem uporabnog modela ako nije patentibilan u povodu zahtjeva nositelja za provedbu postupka potpunog ispitivanja izuma koji je zaštićen uporabnim modelom (pretvorba uporabnog modela u patent, čl. 77. ZP-a). ${ }^{52} \mathrm{U}$ registar se patenata upisuje podatak o prestanku vrijednosti uporabnog modela s naznakom pravnog temelja, dana prestanka te opsega prestanka (čl. 22. t. 21. ZP-a). Prestanak se uporabnog modela objavljuje u glasilu DZIV-a (čl. 24. ZP-a).

\section{ZAKLJUČAK}

Novim Zakonom o patentu iz 2020. godine uveden je novi oblik zaštite izuma uporabnim modelom, a koji je zamijenio konsenzualni patent. Nositelj uporabnog modela stječe isključivo pravo iskorištavati i raspolagati izumom koji je predmet zaštite danom objave registracije uporabnog modela te ga treće osobe mogu iskorištavati samo uz odobrenje njegova nositelja. Uporabni model traje deset godina od dana podnošenja prijave uporabnog modela, uz plaćanje troškova godišnje naknade za održavanje prava. On se može prenijeti te ustupiti na korištenje trećoj osobi, naslijediti, založiti, ovršiti te biti dio stečajne mase. Određeni se izumi ne mogu zaštititi uporabnim modelom.

U odnosu na ranije pravno uređenje postupka za priznanje konsenzualnog patenta, postupak za registraciju uporabnog modela znatno je brži i jeftiniji. Postupak se pokreće podnošenjem

$50 \quad$ ZP iz 2003. godine je u čl. 95.f st. 2. predviđao mogućnost da nositelj konsezualnog patenta podnese tužbu za naknadu štete protiv trećih osoba koje su neovlašteno koristile konsenzualni patent, da uz nju podnese i dokaz da je DZIV-u podnio zahtjev za priznanje patenta provedbom postupka potpunog ispitivanja prijave patenta. U njemačkom pravu § 24.-24.g GebrMG-a, a u austrijskom pravu § 41.-45. GMG-a uređuju građanskopravnu zaštitu uporabnog modela koja je jednaka zaštiti patenta. Pritom se u tim pravima u postupku registracije uporabnog modela provodi pretraživanje stanja tehnike i izrađuje izvješće o tome.

51 Nositelj se uporabnog modela može odreći prava u cijelosti ili djelomično pisanom izjavom. Učinci izjave o odricanju nastupaju sljedećeg dana od njezine dostave DZIV-u. Ako je u registru uporabnih modela upisano određeno pravo u korist treće osobe, mora se dostaviti i ovjerena pisana suglasnost te osobe.

52 Iste razloge za prestanak uporabnog modela predviđa i § 23. GebrMG-a, §12. GMG-a te čl. 24. prijedloga Direktive. U njemačkom i austrijskom pravu nije moguće tražiti pretvorbu uporabnog modela u patent. 
prijave uporabnog modela DZIV-a, pri čemu se ograničava broj patentnih zahtjeva. DZIV utvrđuje datum podnošenja prijave uporabnog modela i provodi njezino formalno ispitivanje. $\mathrm{Ne}$ provodi se pretraživanje stanja tehnike niti se ispituje novost, inventivna razina te industrijska primjenjivost izuma. U usporednom se pravu u postupku za registraciju uporabnog modela predviđa provedba pretraživanja stanja tehnike i izrada izvješća o tome. To se izvješće može izraditi na zahtjev podnositelja prijave ili je ono obvezatno, ali nisu obvezatni rezultati pretraživanja u daljnjem postupku. Njegovom se izradom povećava opstojnost pravne zaštite registriranog uporabnog modela u budućnosti te može poslužiti kao podloga za eventualnu pretvorbu prijave uporabnog modela u prijavu patenta. Stoga bi bilo korisno da se to omogući i u hrvatskom pravu.

ZP dopušta da se za isti izum za koji je podnesena uredna prijava patenta, podnese i prijava uporabnog modela u propisanom roku. Pritom se podnositelj prijave uporabnog modela može pozivati na prvenstvo prijave patenta. To omogućava tzv. grananje prijave patenta i prijave uporabnog modela za isti izum, čime se štite izumi s kraćim vijekom ekonomskog iskorištavanja u razdoblju od podnošenja prijave do donošenja rješenja o priznanju patenta (pendentni patenti). Ako isti izum kasnije bude zaštićen patentom, prestaje uporabni model.

Posebnost je hrvatskog prava da nositelj uporabnog modela može zahtijevati od DZIV-a provedbu postupka potpunog ispitivanja izuma koji je zaštićen uporabnim modelom, čime se on pretvara u patent. Taj zahtjev može podnijeti najkasnije do isteka sedme godine trajanja uporabnog modela te ga ne može povući. Ovisno o rezultatima postupka potpunog ispitivanja uporabnog modela, DZIV može donijeti rješenje o priznanju patenta ili o proglašavanju uporabnog modela ništetnim.

Tijekom postupka za registraciju uporabnog modela treće osobe ne mogu stavljati prigovore na prijavu uporabnog modela te se ona ne objavljuje. One mogu naknadno tražiti poništavanje uporabnog modela u cijelosti ili djelomično za cijelo vrijeme njegovog trajanja ako nisu bili ispunjeni uvjeti za njegovu zaštitu. Pri ocjeni patentibilnosti izuma primjenjuju se isti kriteriji kao i za izum zaštićen patentom (novost, inventivna razina, industrijska primjenjivost). To omogućava naknadnu kontrolu osnovanosti pružanja zaštite izuma uporabnim modelom.

Nositelju se uporabnog modela ne priznaje građanskopravna zaštita prema osobama koje neovlašteno koriste izum koji je predmet zaštite. Tu će pravnu zaštitu moći ostvariti samo ako naknadno zatraži pretvorbu uporabnog modela u patent. To slabi atraktivnost uporabnog modela te stupanj zaštite koji pruža. U usporednom se pravu nositelju uporabnog modela daje jednaka građanskopravna zaštita kao i nositelju patenta. Stoga bi bilo korisno izjednačiti nositelja uporabnog modela s nositeljem patenta, odnosno dopustiti mu podnošenje tužbe za naknadu štete protiv osoba koje su neovlašteno koristile zaštićeni izum. Podnošenje te tužbe bi se moglo uvjetovati prethodnom provedbom pretraživanja stanja tehnike i izradom izvješća o tome.

\section{BIBLIOGRAFIJA}

1. Königer $\mathrm{K}$, 'The $125^{\text {th }}$ anniversary of the German utility model: A reason to celebrate?' (2017) 12(2) Journal of Intellectual Property Law and Practice 75

2. Radauer A and others, Study on the economic impact of the utility model legislation in selected Member States: Final report (Publications Office of the European Union 2014) 
3. Verona A, Pravo industrijskog vlasništva (Informator 1978)

\section{PROPISI I DOKUMENTI}

1. Amended proposal for a European Parliament and Council Directive approximating the legal arrangements for the protection of inventions by utility model (2000/C 248 E/03) COM(1999) 309 final - 97/0356(COD) [2000] OJ C248 E/56

2. Gebrauchsmustergesetz (BGBl 211/1994) (AT)

3. Gebrauchsmustergesetz (BGBl I S 1455/1986 und I S 2541/2017) (DE)

4. Uredba o naknadama za posebne troškove i troškove za pružanje informacijskih usluga Državnog zavoda za intelektualno vlasništvo (NN 109/2011, 96/2013, 89/2020) (HR)

5. Zakon o obveznim odnosima (NN 35/2005, 41/2008, 125/2011, 78/2015, 29/2018) (HR)

6. Zakon o parničnom postupku (SL SFRJ 4/1977, 36/1977, 36/1980, 6/1980, 69/1982, 43/1982, 58/1984, 74/1987, 57/1989, 20/1990, 27/1990, 35/1991 - NN 53/1991, 91/1992, 112/1999, 129/2000, 88/2001, 117/2003, 88/2005, 2/2007, 96/2008, 84/2008, 123/2008, 57/2011, 148/2011, 25/2013, 89/2014, 70/2019) (HR)

7. Zakon o patentu (NN 16/2020) (HR)

8. Zakon o upravnim pristojbama u području prava intelektualnog vlasništva (NN 64/2000, 160/2004, 62/2008, 30/2009, 49/2011) (HR)

\section{MREŽNI IZVORI}

1. Nacrt prijedloga Zakona o patentu (Vlada Republike Hrvatske, Zagreb, travanj 2019) <https://esavjetovanja.gov.hr/Econ/MainScreen?EntityId=10742> pristupljeno 22. siječnja 2021.

2. Prijedlog Zakona o izmjenama i dopunama Zakona o patentu, s konačnim prijedlogom Zakona (Vlada Republike Hrvatske, Zagreb, Svibanj 2007) <https://www.iusinfo.hr/AppendixExtCro/RDOCSB_HR/ent_id_1684.PDF> pristupljeno 22. siječnja 2021.

3. Statistika industrijskog vlasništva (Državni zavod za intelektualno vlasništvo, siječanj 2021) <https:// www.dziv.hr/hr/o-zavodu/statistika-ind-vlasnistva> pristupljeno 1. siječnja 2021.

4. Što je uporabni model? (Državni zavod za intelektualno vlasništvo) <http://dziv.hr/hr/intelektualno-vlasnistvo/patenti/sto-je-uporabni-model> pristupljeno 18. siječnja 2021.

5. Utility models (European Commission) <https://ec.europa.eu/growth/industry/policy/intellectual-property/patents/utility-models_en> pristupljeno 18. siječnja 2021.

6. Utility models (World Intellectual Property Organization) <https://www.wipo.int/patents/en/topics/ utility_models.html> pristupljeno 18. siječnja 2021. 
Dionis Jurić*

\section{THE UTILITY MODEL AS A NEW FORM FOR THE PROTECTION OF INVENTIONS}

\section{Summary}

The utility model is a new form for the protection of inventions introduced in the Croatian law by the Patent Act of 2020. It entitles the utility model owner to exclusive right to use and dispose of the invention that is the subject of protection from the date of publication of the utility model registration. The utility model protection validity is ten years from the date of submission of the utility model application, with the payment of the annual maintenance fee. The utility model registration procedure is initiated by a special application. The State Intellectual Property Office examines its conformity with the law and does not examine the novelty, inventive step and industrial applicability of the invention. It does not compose the search report of the state of the art. Certain inventions cannot be protected by the utility model. The Patent Act allows branching off a utility model application from a patent application for the same invention. It also allows conversion of the patent application to a utility model application and vice versa. The utility model owner may request a full examination of the protected invention by the State Intellectual Property Office and conversion of the utility model into a patent. This request may be submitted no later than the end of the seventh year of the validity of the utility model protection. Third parties may request the declaration of nullity of the utility model during the whole period of its validity. The utility model owner is not entitled to sue the persons who infringe his exclusive rights.

Keywords: $\quad$ utility model, registration procedure, conversion of the application, conversion in a patent, declaration of nullity, right on lawsuit 
